\title{
Content Area Pre-service Candidates Learning Language Teaching with Adolescent Immigrants in an Urban PDS Middle School
}

\author{
Yanan Fan \\ San Francisco State University \\ yanan@sfsu.edu
}

\begin{abstract}
How do teacher candidates develop their knowledge in second language literacy to support their students in a Professional Development School (PDS)? This article reports preliminary findings of a qualitative study that investigates the learning process of single-subject credential candidates in a pilot urban PDS site where they co-taught and co-learned in an English Language Development (ELD) program through an on-site seminar credential class. Data collection included, but was not limited to, researcher observational fieldnotes, candidate reflections, term papers, and transcripts of interviews and performances. The study finds that in an interactive, social learning space created by the PDS setting, teacher candidates challenged their assumptions about learning English among immigrant students, as well as identified language learning opportunities in traditional worksheet-based activities and a communicative project.
\end{abstract}

Keywords: teacher education, second language literacy, English language learners, professional development schools.

\begin{abstract}
Dear Fanglin ${ }^{1}$, I loved the puppet show you and your class performed and had fun helping you prepare for it. It made me very proud to watch you on stage. You pronounced all the words perfectly and paused after every exclamation point. You even put emotion into the words, and all of that while so many people were watching! My time at Bayside is almost over and I will be teaching my own class very soon. I will always remember you greeting me every Wednesday with a big smile and a warm hello. Thank you Fanglin, good luck in your studies! Best wishes, Ms. Kristen (Teacher Candidate, note to Fanglin, her student partner, at the end of the semester)
\end{abstract}

Fanglin is a recent immigrant student in an American public school, as the student population has been undergoing steady demographic changes in the country over the past decades. With an increasing enrollment rate from ninety to ninety-three percent between 1980 and 2009, the number of school-age children who spoke a language other than English at home rose from 4.7 to 11.2 million, or from ten to twenty-one percent of the population in this age range (U. S. Department of Education, 2012). Language diversity has become the new norm in everyday school life. In California, for example, the percentage of public school students participating in programs for English language learners (ELs) rose from twenty-six percent to twenty-nine percent between 2002 and 2011 (U. S. Department of Education, 2013). There were about 1.4 million ELs in public schools in 2011-2012 (California Department of Education, 2013). Since the No Child Left Behind Act of 2001, accountability and standardized testing have become pressing

\footnotetext{
${ }^{1}$ All names are pseudonyms.
} 
buzzwords for educational policies in the United States. This in turn has increased the number of ELs in mainstream classrooms without making good use of their L1 resources and without preparing teachers accordingly (Lucas \& Villegas, 2013). Despite the demographic changes, research shows that mainstream teachers are not sufficiently prepared for ELs (Waxman \& Tellez, 2002; Rubinstein-Avila \& Lee, 2014), especially those in secondary schools who struggle between low academic achievement and high dropout rates (Major, 2006). School teachers, like Kristen, urgently need the experience and pedagogical, linguistic knowledge to address the challenges of students like Fanglin.

Educational researchers have put forth several theoretical frameworks to guide teacher preparation programs in the new era of linguistic diversity. For instance, Fillmore and Snow (2002) lays out what classroom teachers need to know about language, from oral to written, and from socialization to academic language. Lucas, Villegas, and Freedson-Gonzalez (2008) describes linguistically responsive pedagogical practices to promote candidates' awareness and understanding of teaching language and content at the same time. Turkan, de Oliveira, Lee, and Phelps (2014) proposes a disciplinary linguistic knowledge base for teachers to understand and model the academic discourse of their content areas in order to further engage ELs. To operationalize these principles, the researchers argue for well-designed university courses on the linguistic, sociolinguistic, and sociocultural aspects of language learning and teaching (Fillmore \& Snow, 2002), well-grounded assessment of linguistic knowledge of content areas (Turkan et al., 2014), and field opportunities for candidates to spend time and complete required coursework with ELs (Lucas, Villegas, \& Freedson-Gonzalez, 2008).

In practice, scaffolding and differentiation based on clear understanding of language demands and goals are among the many effective pedagogical strategies for ELs. They are widely discussed in teacher preparation programs and assessed (e.g., in the Performance Assessment for California Teachers that has been adopted by teacher preparation programs nationwide). ${ }^{2}$ The strategies refer to careful instructional steps to make content accessible and to modify learning tasks according to the strengths and needs of ELs at various stages of mastery of English (see Rothenberg \& Fisher, 2007). However, research shows that some secondary teachers feel illprepared in this regard (e.g., Rubinstein-Avila \& Lee, 2014) because of "limited preparation for teaching content to ELs” (p. 189). When observing closely in the classroom, researchers find that such frequently-visited topics as differentiation, grouping, and scaffolding in methods courses are not being translated smoothly into effective classroom teaching (Coady, Harper \& De Jong, 2015). The perilous gap between university courses and classroom teaching is evident, as the researchers argue.

To fill the gap between theory and practice, researchers study programs that attempt to contextualize teacher preparation in a sociocultural process of language learning in EL communities (Coady, Harper, \& De Jong, 2015; García, Arias, Murri \& Serna, 2010). For instance, small-scale research projects in credential courses assign case studies of ELs and their communities to push candidates' understanding of their challenges and resources. Jurchan and Morano (2010) documents a case study project in which teacher candidates collected extensive qualitative data from their one-on-one tutoring experience with $\mathrm{K}-12 \mathrm{ELs}$, as well as data from the institutional definition of ELs via test scores, policies, and resources. The purpose is to raise candidates' awareness of the sociopolitical impact on learning, the crucial role classroom teachers play in EL's development, and the nature of language learning. Besides course-based research projects, candidates are introduced to service-learning activities to develop empathy and

\footnotetext{
2 See https://scale.stanford.edu/teaching/pact

Journal of the Scholarship of Teaching and Learning, Vol. 18, No. 2, June 2018. josotl.indiana.edu
} 
pedagogical skills to work with ELs (e.g., Fan, 2013; Hadjioannou \& Hutchinson, 2010). In a graduate social studies methods course, twelve teachers designed and conducted a serve-learning, interdisciplinary project to encourage their elementary school students to become critical thinkers and activists for social change (Ponder, Veldt, \& Lewis-Ferrell, 2011). Dove and Honigsfeld (2010) describes seven co-teaching models in a K-12 setting that involve collaborations among inservice teachers in various departments - ELD, general education, and subject areas. The collaborations encourage positive dispositions and strong leadership among teachers in supporting ELs.

Still, researchers and teacher educators have yet to investigate what it looks like for preservice content area teachers to understand language learning and teaching in a community of ELs. Many existing studies either are limited by the scope and time of a university course isolated from ELs or involve only elementary school teacher candidates. More research on secondary school candidates' learning with (rather than about) ELs and about effective teaching (and learning) strategies for ELs is needed.

\section{PDS as Social Learning Spaces for Language Learners and Teachers}

Professional development schools (PDSs), first proposed by the Holmes Group in 1986, offer both a practical platform for meaningful field experiences and a reflective tool with which teacher candidates integrate first-hand knowledge about students into teaching, and theory into practice, under the tutelage of schoolteachers and university instructors (Gebhard, 1998). The PDS is a descendant of the laboratory schools of the early $20^{\text {th }}$ century. Guided by an inquiry approach, candidates learn to plan, teach, and work alongside more experienced teachers. University- and school-based faculty also work collaboratively to design and implement PDS learning experiences for new teachers, as well as for school children. Teacher education is thus transformed from the front-loading of knowledge and skills in teaching and management to experimentations through direct and regular collaboration with school sites. Wong and Glass (2011) write that PDSs have changed

(1) what student teachers did instructionally during their student teaching and field experiences; (2) how student teachers engaged more broadly with school sites and pupils; (3) how university faculty members interacted with school teachers and, more important, pupils; and (4) how cooperating teachers and other school personnel were prepared to partner with university faculty members and candidates to design and deliver instruction... These innovations all contributed to building a foundation - of new relationships, new roles, new practices, new dispositions - on which all adults increasingly focused on student learning and their contributions to it (p. 407).

PDSs are often documented in the research literature as intervention tools that promote self-reflection. They may, for instance, be led by an experienced school teacher to observe students with learning disabilities, plan an instructional intervention, and assess and compare student performance (Baker, 1999). In other cases, teacher candidates are part of the institutional operations that provide resources to students, their parents, and communities (Trachtman, 2007). On this highly contextualized, communicative platform, teacher candidates gain insights into and reflect on the learning process and their own teaching effectiveness as tutors, whereas struggling students receive focused instruction and one-on-one attention. 
Sharing the four goals of PDSs to "enhance pupil learning, improve field experiences for candidates, engage K-16 educators in continuous and targeted professional development, and use action research to inform teaching and learning in schools” (Wong \& Glass, 2009, p. 8), a PDS can be viewed as a set of "social learning spaces" (Basile \& Gutierrez, 2011, p. 520) where all participants - K-12 teachers, students, staff and administration, university faculty, and teacher candidates - bring expertise and resources to their learning partners and at the same time "negotiate the mutual relevance of their respective experience" (Wenger, 2009, p. 5). More than a decade ago, scholars recognized the potential benefits of PDS to all participating members in second language teacher education (both the world language teachers and the English as a second language teachers), for it creates meaningful opportunities for candidates to become ethnographic observers and classroom-based researchers to examine and reflect on skills, beliefs, and practices (Vélez-Rendón, 2002). Even though "[o]nly one publication was located that describes a PDS partnership between a foreign language teacher education program and a local school” in VélezRendón's review in 2002 (p. 465), Wong and Glass (2011) examined new literature since then and finds many narrative accounts of how PDSs significantly transform the teacher preparation program by, for instance, using student teachers as tutors in their field experience. Beyond language learning and teaching, Gebhard (1998) reveals through descriptions and analysis of a PDS between an elementary school in Los Angeles and a California State University that the practice nurtures leadership, develops the recruitment and induction of new teachers, and creates communication structures for candidates to reflect on their learning as teachers and to investigate student learning over time, among many other benefits.

The social spaces provided by the PDS are vital in terms of a sociocultural perspective on learning as dynamic social practice in which every participant plays an active role in constructing the experience and in using language as a symbolic tool (Rogoff, 2003; Vygotsky, 1978). For language teachers, "the capacity of persons, the organization of verbal means for socially defined purposes, and the sensitivity of rules to situations” (Hymes, 1972, p. 71) can be investigated, designed, and negotiated, respectively, in a context where traditional front-loading of theory and method gives way to purposeful partnership with language teachers in local schools, outside university seminar courses. In such spaces, teachers and students share past experiences, understand their changing social roles in relation with other participants, anticipate actions through the interaction of situations and events, and study how language itself works in the classroom - a community of practice - on a daily basis (Hymes, 1974; Lave \& Wenger, 1991). For language teachers, the PDS offers a natural setting for a variety of communicative and authentic activities (e.g., participants checking on project progress, sharing ideas and experiences, or having more focused one-on-one conversations) that directly benefit student learning.

Houston, Hollis, Clay, Ligons and Roff (1999) studies the impact of PDS on candidates' instructional practice and knowledge using mixed methods with participants from across elementary and secondary schools in Texas. The researchers found that due to longer time in schools, broader school-based collaborative activities, and extensive supervision, candidates were able to interact more effectively with students in the classroom in teaching and classroom management. Similarly, in a larger mixed-methods project that covers 12 PDS sites and about 180 participants (PDS candidates, non-PDS candidates, master teachers) in Equity Network PDS in California, Wong and Glass (2005) report on more positive learning outcomes for PDS candidates, which include better mentor relationships, classroom experiences, and understanding of urban schools and diverse student populations. A review of similar research between 2000 and 2010 on the impact of PDS preparation on teacher candidates reports that candidates use more varied teaching methods, have more knowledge about school and community beyond the 
classroom, and are ready to teach in urban settings (Castle \& Reilly, 2011). Although studies of deliberate programming for PDS candidates on school campuses include intervention tutoring and curriculum projects that target underrepresented and high-needs students and particular content areas in PDS (see Wong \& Glass, 2011), little is known regarding what has been done with ELs in PDS classrooms.

Given the need for situating teacher preparation in community-based practices and the gap in literature on candidates' learning with ELs in a PDS setting, this article describes the preliminary findings of the learning process of single-subject credential teacher candidates in an urban PDS middle school where they co-taught and co-learned in an ELD program. In particular, the article aims to contribute to the urgent need in teacher education to facilitate teacher candidates' inquiries into second language learning in order to address the changing demographics in public schools. The author asks how candidates develop their knowledge in second language literacy to support their EL partners in this PDS setting. The project reported in this article was a pilot before the institutionalization of a PDS partnership with the middle school and its district; nonetheless, findings will shed light on ways to create conditions for effective teacher preparation for language diversity and sustainable collaboration with local school communities.

\section{The Site}

Bayside Middle School serves over 500 students from a socioeconomically disadvantaged and ethnically diverse community in a major California city. As a result of the district restructuring efforts in some neighborhood schools, Bayside, whose student body was primarily Latino, African American, and Pacific Islander, witnessed a sharp increase in student population in the past several years, with recent immigrants in particular. In 2011, more than forty percent of its students were classified as ELs. The number has since then been steadily rising as new students arrive at various points of time during the academic year. Despite the fact that the school celebrated a 40-point gain in the API in the 2010-2011 academic year across all ethnic groups and a high attendance rate of $98 \%$, one urgent challenge is addressing the needs of the influx of immigrant students (all classified as ELs) and the need for effective instruction to which they are entitled.

One solution that Bayside implemented was to reconfigure its ELD department from a one-room one-teacher program to a three-classroom, multilevel, multi-subject matter program. The ELs were grouped into three morning English classes of basic, basic-to-intermediate, and intermediate-to-advanced levels, based on students' language testing results from the California English Language Development Tests (CELDT). Afternoon ELD courses were content based. Students were regrouped into 6th, 7th, and 8th grade-level math, science, and social studies classes taught by the same three instructors respectively. The three ELD teachers planned both a morning language course and three afternoon content-based courses for math, science, and social studies. With the help of a literacy coach sent from the district, they also co-planned under the state English language development standards. Even though the new class configuration was designed to support student learning in both English and other subjects, classroom instruction was challenging due to lack of resources and manpower when much differentiation was needed to address a range of language levels, according to the lead ELD teacher at Bayside. On the one hand, some students were close to ready for mainstream classrooms because of their knowledge of the subject matter and improved English proficiency; on the other hand, two to three new immigrant students with little exposure to English arrived every month, posing a great challenge to instructional planning for both the language class and the subject matter. 


\section{Context of the Study}

With the university's mission to better prepare candidates for ELs and Bayside's need to better serve its students, a Northern California public university and Bayside initialized a PDS pilot. At its earliest stage, the program enrolled twenty-five teacher candidates in a three-credit-bearing teacher education seminar course taught on the Bayside campus, making it possible for candidates to have regular contacts with their EL students and collaborating teachers. Among the twenty-five candidates, fourteen were female and eleven male. They were trained in a variety of subjects, namely English language arts (4), Math (4), Science (3), Social Studies (9), Physical Education (3), and Art (2). Except for five candidates who regularly spoke Cantonese, Tagalog, or Spanish at home, others identified themselves as monolingual with minimum exposure to and experience with EL students. Twenty-one reported that this was their first time focusing on EL and second language development processes. At Bayside, about forty ELs participated in the study. They were $6^{\text {th }}$ and $7^{\text {th }}$ graders speaking Spanish, Chinese (Mandarin and Cantonese), Arabic, and Tagalog. Three ELD teachers and the school principal also joined the team effort to have the students meet the teacher candidates regularly for planned language learning activities throughout the semester.

This ethnographic case study (Emerson, Fretz, \& Shaw, 1995) required detailed and meticulous data collection and analysis. The university professor collected an extensive dataset that included fifty researcher fieldnotes and analytic memos detailing class activities, two surveys and ten candidate journals on progress and struggles, thirty hours of audio and video clips of third period partner time, two hours of video footage of an end-of-semester puppet show, EL information (proficiency level, demographics, etc.), correspondence among participants, and interview transcripts, during the semester-long team planning and instruction. Analysis of the dataset in its entirety involved repeated reading, organizing and categorizing of data. Guided by the research question of how candidates develop and reflect on their knowledge in second language literacy to support their EL student partners in a PDS setting, the inductive process (Emerson, Fretz, \& Shaw, 1995; Erickson, 1986) entailed organizing all data by candidate name, by ELD class, and in chronological order. After reading the whole data set multiple times, the researcher/university professor developed preliminary coding around (a) candidates' knowledge of home languages (L1) and second languages (L2) development (e.g., communicative competence, language transfer); (b) the kind of instructional decisions that responded to this knowledge (e.g., teaching vocabulary, writing, pronunciation); (c) the ways that (a) and (b) interrelated over time and influenced candidates' previous experience, assumptions, and knowledge building; and (d) different geographic, cultural, and social spaces made possible in PDS settings and their impact on candidate learning. The findings will shed light on innovative ways and conditions to support content area teachers to be better prepared for ELs. The following sections illustrate how an EL-focus PDS model was created for the candidates and the ELs, what knowledge about learning English the candidates focused on over time, and how working with ELs and other teachers benefitted their development as language teachers during the 14-week long on-site credential training at Bayside.

Journal of the Scholarship of Teaching and Learning, Vol. 18, No. 2, June 2018.

josotl.indiana.edu 


\section{Building a Learning Village: An EL-focus Model}

One vital factor to promote language learning is creating an environment that values the sociocultural nature of learning among all students and their support system (Lopez \& Iribarren, 2014). It truly takes a village. This PDS community, the "village," hosts EL students and teacher candidates, as well as ELD teachers, each playing an active role in the cultural practices of learning and teaching (Lave \& Wenger, 1991). In a preparation program that rigorously addressed equity, social justice, and culturally responsive pedagogy, the majority of the candidates felt excited to meet ELs in person, but "worry [they] may fail miserably in front of [their] ELs" (Candidate survey results). Their initial survey revealed that $70 \%$ of the candidates doubted their ability to help ELs as language teachers. To scaffold their learning with the ELs, a collaborative learning community was created to respond to the particular resources in the Bayside school community and an interdependent relationship among all involved. This learning community was structured in such a way that language practices were spontaneous, fluid, and responsive to the actual interactions among members in an anxiety-free environment. The seminars at Bayside made it possible for candidates to share time and space with ELs on a weekly basis. Thanks to this group effort, the three-hour seminar was divided into two regular segments - planning and reflection among candidates, and classroom observation and group work with ELs. The former was dedicated to such seminar content as language learning theories and lesson planning; the latter to team projects with ELs.

As Figure 1 reveals, all members had something to offer to, and learn from one another. Candidates worked closely with ELs with support from the university professor and ELD teachers on teaching strategies and disposition. Through teamwork, candidates observed their EL partners, participated in their language learning activities, and reflected on the transformation of their understanding and skills (Vélez-Rendón, 2002). ELs, at the center of the community, were not the receivers of language instruction, but active producers of English with attentive listeners and helpers around them. In their letters to their student teacher partners, many students expressed how "free" and "confident" they felt when their "friend teachers" were truly interested in their stories and questions. The collaborative practice is not an intervention by a distinct learning/teaching method, but rather the construction of a "village" where members make sense of, and aim at, the most productive ways to learn English with less anxiety and in their own pace (Lucas \& Villegas, 2013). 


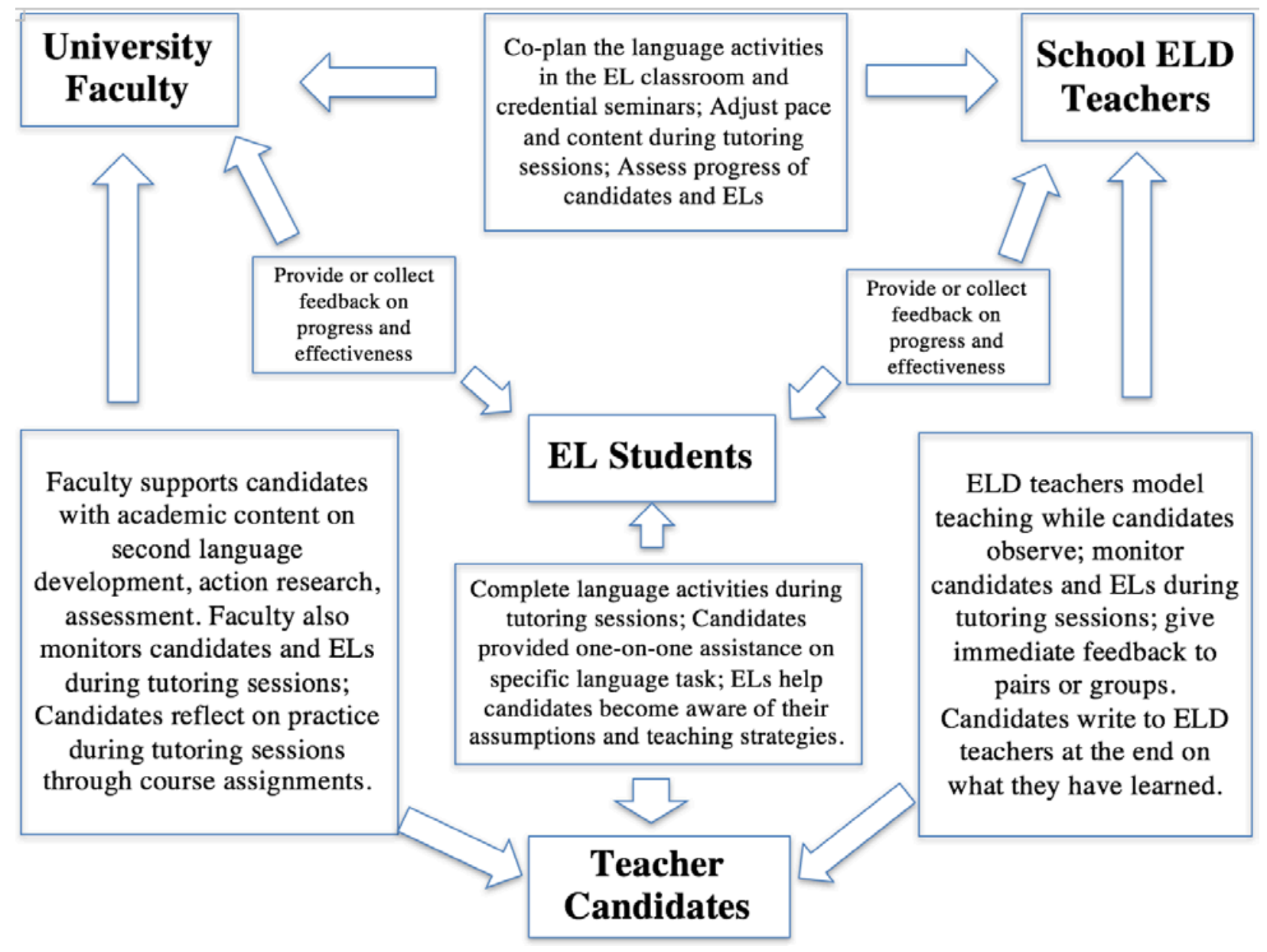

Figure 1. An EL-focus PDS model at Bayside.

\section{Reflecting on the Basics of the English Language}

The safe and stress-free learning environment promotes candidate understanding of what develops in language learning and how to make language learning happen in classrooms. It was clear on the candidates' first day in the ELD classrooms that the main learning activities - lectures, teacher-led discussions, and worksheet routines - were centered around the building blocks of English language vocabulary, grammar, and sentence structures, or the "basics" (Dyson, 2013). The textbook-based ELD instruction at the beginning of the semester reflected a strong influence from traditional views of language learning as a linear progression of acquiring linguistic features (Valdés, 2001); still, it presented the reality and authenticity of language instruction for ELs in public schools. From spelling, pronunciation, word definition to functions, tense, parts of speech, and from worksheets to inquiry, the candidates examined, through observation, how students responded to the basics and explored conditions where the basics could truly become useful tools for students.

\section{Form vs. Meaning}

During a typical grammar activity on present participles, Kristen, Ada, and David were discussing with three students how the praying mantis got its name. The plan was to explain that the present 
participle - a verb in its -ing form - can be used as an adjective to describe a noun - a performer of the action identified by the participle. The group conversation, however, grew into distinguishing two intriguing phrases, the praying mantis versus the preying mantis. Both seemed to make sense at first. Kristen described herself as "stumped" as her student.

I did not know the answer [to how the praying mantis gets its name before reading the grammar note on present participles]. I assumed it was because it looked like it was praying, but then I heard David explain it was because it preyed on its male partner. What was confusing for me was the spelling of 'praying' mantis. The 'a' versus the ' $e$ ' in the word meant a world of difference. When I drew a picture of a cross and put my hands together and gestured that I was praying to it, [the student] understood that, but could not see how it related to the mantis (Candidate Kristen, fieldnote).

As documented in their fieldnotes, candidates tried to gesture as in prayer, comparing the postures of a prayer and a mantis. They took turns to argue how "praying” or "preying” would help convey the image and actions of a mantis. Students nodded and tallied their vote on "praying" or "preying" with the help of their digital dictionary. Several Chinese girls believed that "preying” was appropriate because the mantis was "a good (skillful) predator" rather than "a quiet person in a temple." The group enjoyed a conversation that "transformed [present participles] from static rules to communicative resources” (Dyson, 2013, p. 5). The negotiations reminded the candidates that "[l]earning and teaching English should not just focus on grammatical rules (though I do need to review my own knowledge in grammar). Rather, students need to communicate meaning while learning to use the grammar tools” (Candidate Ada, fieldnote). This revelation is no new knowledge, as the notion of communicative competence in language learning, together with best practices to promote students' communication skills, has been highlighted in second language learning textbooks and scholarly publications (Richards \& Rodgers, 2014; Rothenberg \& Fisher, 2007). Nonetheless, it was only after a conversation with their ELs about what foundational, linguistic, and sociolinguistic knowledge makes sense in their learning and how students made sense of the basic language features (in this case, the grammatical function of a gerund) that the candidates started examining the rules of the language and ELs' response to the basics.

\section{Impact from First Language}

Similarly, the groups tackled confusions about parts of speech and the semantic (or pragmatic) use of utterances. For example, Wayne documented an exchange with his student, Jack, when he greeted him one day.

I sit down and ask him, "Hey Jack, how are you doing?” I get the regular response, "huh?” So, I repeat it again, but slowly. He hears me better this time and answers me, “Oh, one-fifty and one-sixty.” I’m confused so I ask him to repeat it, "huh?” He points to his book and says, "I'm doing one-fifty and one-sixty.” I realize that he thinks I had said, "What are you doing?" as opposed to "How you are doing?” So I emphasize to him that I asked how he was doing. I gave him ideas of what he can say in response to someone asking him that. "How you are doing? So, you can say, 'I'm doing well.' Or you can say, 'I'm tired.”' He nods and we move on (Candidate Wayne, fieldnote). 
Many candidates shared Wayne's experience. In their reflection, the candidates agreed that EL students might not be so attuned to minute changes in language form (how vs what in the sentence) as native speakers until experimenting with the language in real social interactions. In Mandarin, which is Jack's L1, the word "do(ing)" would make better sense based on translation if paired with "what" than with "how," and would not have any indication of general greeting. Jack's puzzled look and unexpected response suggested a need for candidates to offer a comfortable environment for ELs to play with the language without feeling humiliated and more importantly, to show ELs how they are using their L1 to help convey the meaning. This critical discussion on the transfer from L1 to L2 (English) will build ELs analytical skills in learning the language.

\section{Sounding Out vs. Comprehension}

One commonly shared struggle among candidates was ELs' not yet "being able to sound out reasonable spellings” (Dyson, 2013, p. 3), by breaking sentences and words down to syllables. In their journals, candidates argued strongly in favor of getting students' pronunciation and intonation right, or creating a beat, as described by Andy.

After a few times saying it [photosynthesis] slowly, I would ask [my student] to say the word faster in the tune of a catchy beat. The process of picking up the beat made her memorize the way it should be said when she saw the word again. Creating a beat to the word made it fun and helped [her] retain the proper way to pronounce photosynthesis in a fun way (Candidate Andy, fieldnote).

However, candidates soon realized that sounding out was not helping students with their understanding of texts, even though they believed otherwise at the beginning of the collaboration before course readings and discussions. Anne was one of the few candidates noticing her students' struggle, as well as her own.

I could tell [my students] strive to understand English in every aspect of the language and were working very hard at it, but perhaps I should not have thought that they would get it after several rounds of reading aloud (Candidate Anne, fieldnote).

Beth further detailed a failed attempt to rely on sounding out to strengthen reading comprehension.

I try to get [my student] to read the sentences out loud so that he is reading for meaning, but he dismissed my attempts to get him to refocus. He would rather just look up the words or try to guess so that he can get the meaning faster (Candidate Beth, fieldnote).

Discussions about why the seemingly natural, basic sounding-out activity failed to work took place in the on-site seminar that the university professor facilitated. Speaking from their experience with the students, the candidates drew the conclusion that without a thorough understanding of second language learning, their intuition as native speakers to rely simply on sounding-out to teach ELs would not be effective, which was especially true when students' L1s carry different linguistic features and cultural backgrounds (e.g., Osborne-Wilson, Sinatra, \& Baratta, 1989). 
In addition, the candidates identified their students' frustration during collaborative hours when they struggled to express themselves in English despite heavy loads of grammar exercises on language accuracy. Seminar focus thus turned to some fundamental principles of building second language literacy guided by a sociocultural view of language learning (e.g., Zuengler \& Miller, 2006), as well as a range of teaching strategies (e.g., Rothenberg \& Fisher, 2007). The candidates analyzed worksheet drills that overwhelmingly emphasized the mechanics of English, rather than situating language skills in communication. They also recognized the opportunity the collaborative hours brought all when EL students were equally eager to participate and share ideas.

\section{Co-teaching a Communicative Unit}

With an understanding that language learning is highly contextualized and more complicated than the studying of the basics, the candidates experimented with a pedagogical strategy that pushes meaning-making and interactions. After three weeks of observation and participation in the ELD classroom, a culminating project marked the start of this new experience in which students strived for a more sophisticated and communicative level of language learning. Classroom activities shifted from pattern drills to a holistic learning experience for the ELs. With help from the candidates, the students performed a puppet show using the scripts they wrote based on a selected story $^{3}$. Unlike the one-dimensional, accuracy-driven vocabulary and grammar exercises in phase one, here the ELs had the opportunity to select a short story, learn to adapt the story into a fouract play, write scripts for each act (including stage directions, narration, and dialogues), role-play the acts, and perform on stage before a live audience. As ELs' partners, candidates aimed to address various language demands of this performance-based unit, support their students throughout the project, and reflect on their learning as language teachers.

The communicative project encouraged teamwork by candidates and their student partners. In the seminar, the candidates planned for segments of the unit, aiming to promote clear understanding of the story, accurate script, and effective delivery rather than basic vocabulary and simple sentence structures. Candidates read the stories with their students, negotiated events that were key to the plot, and worked on scripts that would retell the plot, describe personalities, and interpret funny moments. As vocabulary and general comprehension checks were discussed along the storylines, group conversations focused more on personal interpretations of the story. The candidates asked students, for instance, if it was okay to forgive the wolf for blowing down the pigs' houses because of his allergy, or why Mr. Peter never used the last of his three wishes, or which they thought was the most crucial step Rikki-Tikki-Tavi takes to defeat the two snakes. Candidates found that as students tried to share and clarify their thoughts, they were more aware of the text and interested to explore the details.

Writing scripts for the puppet show sounded like a daunting task to the EL students and the candidates at first; however, with guidance from the ELD teacher and the university professor, the collaboration groups treated the writing process as solving a jigsaw puzzle with scaffolding. Candidates prepared slips of paper on which key events and dialogues were printed. They asked

\footnotetext{
${ }^{3}$ Based on students' level, interest, and the ELD curriculum, three ELD classes picked the following books, respectively:

Class A: Scieszka, J. (1996). The true story of three hungry pigs. New York: Puffin Books.

Class B: Aiken, J. (2001). The third wish. Downloadable at

http://aparker.wiki.hoover.k12.al.us/file/view/The+Third+Wish+by+Joan+Aiken.pdf

Class C: Kipling, R. (1894). Rikki-Tikki-Tavi. Charelston, SC: CreateSpace.

Journal of the Scholarship of Teaching and Learning, Vol. 18, No. 2, June 2018.

josotl.indiana.edu
} 
students to group these cues into four scenes with rationales, then add their own voices in the form of dialogues and narration using a bank of words, phrases, and sample frameworks to organize ideas (e.g., describing events chronologically, turning dialogues into narrative or vice versa). Writing also involved rounds of reading and revising among group members with the candidates taking the lead. As a student in Class A described in her free write, "We rote [sic] the script over [and over again] in our own sentences and our own words. [It] was a little bet trick [sic] but we all did good. And we did it as a group so that made it easer." Group formats changed constantly based on goals. For example, candidates in pairs sometimes worked with a small group of five students who covered the same scene after one-on-one groupwork on specific lines or dialogues.

The rehearsal was "the best time to observe all aspects of language learning taking place at once” (Seminar discussion transcript). During rehearsal, the class practiced reading the scripts aloud first in small groups, then in larger groups, and eventually on stage. The candidates modeled the dialogues, provided feedback, and cued students. Class B's production of The Third Wish was both representative and significant in revealing how contexts and a communicative goal supported learning and provided the students with a "first in life-time performance, and the most exciting experience” (a letter by an EL student to candidates).

The first unforgettable moment was when the candidates role-played the show in front of students to demonstrate how to make the dialogues come to life using tones and gestures. As Bridget documented,

We, as a group, acted out the play garnering the enthusiastic adulation of our student mentees. Everyone did an excellent job, particularly Kent who shrunk himself down to the size of a leprechaun and shuffled around the classroom as the antagonist "Little Man". Laura and Mindy flew around the room as the swan sisters, and the narrators, which included myself, were sure to add the sound effects. We made mistakes, over-acted, laughed a lot and showed the students we too were learners (Candidate Bridget, fieldnote).

At the same time, Candidate Joanna wrote about her student's reaction.

The students really seemed to enjoy the performance. They laughed and applauded and were smiling while we performed. After we completed our acting, Jenny [student] told me that she really liked it and that we are funny. I told her that she can be loud and speak clear and have fun at the same time. She nodded her head and smiled (Candidate Joanna, fieldnote).

Jenny was not the only student who was excited and impressed. Candidate Alyssa documented her session with Abay, who played the lead role of Mr. Peter in The Third Wish.

Abay was eager to make sure no mistakes were made. He especially liked the line Mr. Peter said to his wife, "Mama Mia! You are so Beauuutiful!” We pair-read with other tutors and students through the whole play multiple times. Abay fully embraced his role and turned out to be a great actor. He was the loudest and most expressive student in the class! (Candidate Alyssa, fieldnote).

Journal of the Scholarship of Teaching and Learning, Vol. 18, No. 2, June 2018.

josotl.indiana.edu 
In "a rumble of activity" as Candidate Laura described it, the students were much more relaxed and communicative than before with the scaffolding of the scripts that included both everyday English and "fancy and complicated English" (a student's definition of academic English), which initially sounded intimidating to the ELs. The opportunity to participate in multiple rounds of reading, writing, discussing, and role-playing gave them (as well as the candidates) a sense of purpose and accomplishment. Even Dailan, seemingly the quietest student in the class, volunteered a letter to the candidates. "I liked the reading part, because I learned how to read the text. We now understand [the story] better. I read more fluently. Thank you!” Students' interest and effort were clearly reflected in their stage performance with the handmade puppets. "They tried their best to enunciate their lines, moved across stage, and used body language to demonstrate their emotions against large drawings of a bungalow in India, for example, or with various hand-made hats as the pig and the wolf" (Candidate Cynthia, fieldnote). The school community was their audience, whose laughter and applause filled the auditorium.

This communicative project was enriching to candidates and their students in many levels. First, unlike grammar worksheets, adapting a written story into a performance was motivating, contextually rich, and academically challenging for ELs. For instance, Olivia noticed her student's change immediately after the instructional focus shifted from worksheets to the puppet show.

[My student] pointed out which part of his line was his favorite. I thought this was very sweet. I noticed that he was engaged and motivated in a stronger way because he was actually accountable for the work he was doing. Sometimes with worksheet homework he is in a hurry to finish and just get an answer down. With this assignment, he took a lot of time and care in rehearsing because of the pressure of the eventual performance. I learned just how challenging it is to remember pronunciation rules! (Candidate Olivia, fieldnote)

Candidate Reese expressed her excitement in the project. The experience seemed equally rewarding and motivating to her and her peers.

We had a good time at our table acting out the scenes and getting into character. I think this play is a great idea and exercises many skills that EL students need. They are having the opportunity to practice pronouncing their lines, writing scenes, reading their lines, speaking with intonation, gesturing, speaking loudly and publicly, while also being introduced to American literature. What a well-rounded assignment! (Candidate Reese, fieldnote)

The communicative project brought the community together as candidates and students tried out strategies to improve their scripts and performance together; it also reflected the reciprocal nature of learning, as rightly put by Candidate Lee: "[t]he class really seemed to enjoy watching us perform for them and they stayed focused as we, in very dramatic fashion, with flamboyant and melodramatic gestures, performed the same play they put together, reinforcing the reciprocal nature of learning - they taught us and we taught them” (Candidate Lee, fieldnote). Other candidates, such as Monica, reflected on the design of the project.

The experience of helping [students] prepare for the performance also showed me the importance of scaffolding in teaching English. Rather than having the students write their own play, we chose to have them read an existing one. I think this was a good idea. It gives them immediate practice with written English and pronunciation. Maybe toward the end of the year they could write their own play (Candidate Monica, Fieldnote). 
Indeed, candidates were thrilled to see lights in their students' eyes and confidence in their participation. With a combination of reading, writing, speaking, and performing activities, EL students were happy they could finally "do something in English." In her note to her tutor, Weinan was glad that she was "finally feel[ing] like I can speak English!" She added that she "learned it is not enough for one person to read well. We need team work!” (Student Weinan note, translated from Chinese).

The excitement also derived from the lines in the puppet show that EL students would never be given a chance to practice in class.

I felt very nervous when I did the puppet show because maybe I can't read correctly or the microphone can drop, or I forget how to read the word, but [the teacher candidates] helped me a lot. They read with, taught how to read the words, like read fast some words like baby cobras, or read slow, as the people can understand, and to breathe in some parts, and correct some wrong words that other students wrote. I think I can read better some words, ... relax and just read. I learned is to always practice more and always "follow the flow" (Student Henrique, note to candidates).

It was productive for Henrique and his classmates to learn English through such a content/content-rich activity. "It is magical to follow the flow of the interactions with my students," as Candidate Richard wrote. The contrast between a decontextualized worksheet study of English grammar and an accumulating collaborative project on developing communicative skills offered candidates first-hand experience as classroom teachers and language teachers.

\section{Discussion}

This paper reports how single subject credential teacher candidates understood language teaching and supported middle-school-age ELs during the one-semester intensive fieldwork in the on-site pilot PDS program at Bayside. The most compelling lessons learned in this PDS environment addressed candidates' developing understanding of language teaching strategies and undergirding principles throughout their collaborative project, where they learned to analyze the purpose, process, and results of classroom language exercises. First, the candidates delved into the notion of the basics - the fundamental language tools for writers and speakers to put their ideas together. They found it confusing and counterproductive to explain words without referring them to situations. They argued that students might not notice what differences a change in language form would make in the meaning of a sentence or an utterance until they are contextualized. Candidates' most popular strategy of sounding out words could not fully support students, as correct pronunciation of syllables does not necessarily translate into understanding of meaning. In addition, for students whose L1s are logographic instead of phonologic (e.g., Chinese, see Osborne-Wilson, Sinatra, \& Baratta, 1989), sounding-out as a primary strategy might probably complicate students' learning to communicate meaning. In other words, the first lesson evolved around the realization that language development goes beyond rote memorization of basic grammar, vocabulary, and sentence patterns, and that language development is not simply sounding out letters and words. Instead, language development is a nonlinear, meaning-making process that happens only when learners actively use the language in various social situations with real purposes (Halliday, 1980; Valdés, 2001). 
The second lesson highlighted the importance of planning and organizing engaging and effective activities that offer ELs an opportunity to communicate, as well as basic elements in such a communicative activity. Candidates' experiences and observations in the accumulating puppet show project revealed that when a community of language users makes meaning and shares stories, they also build relationships and understand the symbolic tools (e.g., multiple languages in written and/or oral form) that they use (Dyson, 1997). From selecting key plots for the four scenes to rewriting dialogues to performing the puppet show, the level of creativity, thoughtfulness, and resilience demonstrated by the ELs clearly indicated the conditions for effective language learning, that is, students need opportunities to use the language in contexts when they form, negotiate, and clarify ideas with other members of the class. EL students thrive and feel more motivated to perform well when they perceive they are making progress in learning (Busse \& Walter, 2013). Meanwhile, the candidates experienced a sense of purpose in designing and carrying out a language project, as well as intrinsic and extrinsic rewards in the process (Jackson, 1990).

Student response to the communicative project further testified to the need and meaning of communicative tasks, as well as a supportive learning environment, which foreground a purpose to communicate and connect basic building blocks with the sociolinguistic, pragmatic, and functional skills of delivering (Hymes, 1972). Language as a symbolic and social tool has to be used for a purpose and in a community of participants (Vygotsky, 1978). As seen in the praying mantis discussion, the turn-taking of characters in the puppet show, and the use of tones, gestures, and facial expressions among characters, the negotiation demonstrated how important context is in creating meaningful interactions, and in giving students an opportunity to relate to what they know. For the ELs, the communicative project was much more challenging and stimulating than a multiple-choice worksheet on reading comprehension. With teacher candidates and peers at their side, they shared their ideas, asked questions, and explained their choices. Candidates in turn experienced how they could integrate reading, writing, speaking, listening, and performing to engage students. As most candidates did not have former training in teaching English, the collaboration introduced them to the notion that every teacher is a language teacher (Fan, 2013) because building language literacy skills among ELs lies in teachers' concerted efforts from all subject matters to create opportunities for students to express themselves in English.

\section{Reflection on the PDS}

Bayside as a PDS offered social learning spaces with rich opportunities for candidates to make sense of the language, ELs and teaching, and to "merge theoretical and practical learning" (Darling-Hammond, Pacheco, \& Michelli, 2005, p. 460). First, in this safe, supportive, and productive environment, all parties were actively involved in meaning-making and problemsolving language activities where they supported each other by contributing understanding and experience from their funds of knowledge (Moll, Amanti, Neff, \& Gonzalez, 1992). Because of the rapport and collaboration among all members, this learning community was able to experiment with a highly communicative unit that activated EL interest and passion, eased their fear of failure (Swain, 2013), and pushed for higher expectations in language production (Fillmore, 2014). The PDS setting enriched the social and academic learning of both the students and their teacher candidate partners through supervision from the ELD teachers and the university instructor, who guided the candidates to observe, identify, and inquire how their students responded to the language assignments. 
Second, the PDS setting rendered a reflective approach that encourages candidates to analyze two different curricula focuses - grammar-focused vs. communication-driven - in real classrooms. The successful puppet show project demonstrated that it is possible to create a "permeable" (Dyson, 1997) and yet rigorous curriculum that gives students a role to play and that differentiates language tasks based on their social and linguistic backgrounds (Lucas \& Villegas, 2013; Turkan et al., 2014). In their seminar, candidates constantly asked how a work session with ELs could situate grammatical knowledge in building reading, writing, speaking, and listening, and what scaffolding, other than individual attention and feedback, could be offered. At the same time, they analyzed students' powerful demonstrations of what worked and how they made sense of language form and meaning every week. A combination of weekly journals, interviews, and teaching material critiques further grounded their learning with their ELs. "I honestly could not have asked for a better lesson for these students and for myself as a social study teacher," as candidate Laura noted in her final report on her experience at Bayside.

\section{Implications}

Pre-service teacher education is crucial in the development of linguistically responsive teachers in public schools (Lucas \& Villegas, 2013), in that it lays the foundation for the set of knowledge, skills, and disposition, as well as the inquiry methods needed to understand the complex nature of culturally diverse classrooms. Situated teacher learning in university-school partnership, such as the one described in this study, offers candidates an incentive to understand the need to build specialized knowledge in literacy and second language learning, to create a community of language users, and to work with ELs as active participants in such a community. This practice explored ways to establish a collegial community where such questions as what it means to learn a second language and how to make the learning process meaningful and productive for ELs are explored by teacher candidates, university faculty, and schoolteachers. Such professional development opportunities should be an integral part of teacher education programs to fill the gap between theory and practice. Candidates will be transitioned to systematic training in such areas as lesson planning, instruction, and assessment, along with seminars on equity, social justice, and empathy. Future research is needed to investigate how EL students negotiate multiple resources and learning opportunities made possible by efforts to build community-based teacher education programs.

\section{References}

Baker, B. (1999). Report on teaching at risk children: An instructional model in a professional development school. Waco, TX: Baylor University.

Basile, C. G., \& Gutierrez, C. (2011). Universities, schools, and communities: A new generation of professional development school roles, structures, and governance. National Society for the Study of Education Yearbook, 110, 511-530.

Busse, V., \& Walter, C. (2013). Foreign language learning motivation in higher education: A longitudinal study of motivational changes and their causes. The Modern Language Journal, 97, 435-456. http://www.jstor.org/stable/43651648 
California Department of Education. (2013). Facts about English learners in California CalEdFacts. Retrieved July 8, 2016, from http://www.cde.ca.gov/ds/sd/cb/cefelfacts.asp

Castle, S., \& Reilly, K. A. (2011). Impact of professional development school preparation on teacher candidates. National Society for the Study of Education Yearbook, 110, 337-371.

Coady, M. R., Harper, C., \& De Jong, E. J. (2015). Aiming for equity: Preparing mainstream teachers for inclusion or inclusive classrooms? TESOL Quarterly, 50, 340-368. https://doi.org/10.1002/tesq.223

Darling-Hammond, L., Pacheco, A., \& Michelli, N. (2005). Implementing curriculum renewal in teacher education: Managing organizational and policy change. In L. Darling-Hammond \& J. Bransford (Eds.), Preparing teachers for a changing world: What teachers should learn and be able to do (pp. 442-479). San Francisco: Jossey-Bass.

Dove, M., \& Honigsfeld, A. (2010). ESL coteaching and collaboration: Opportunities to develop teacher leadership and enhance student learning. TESOL Journal, 1, 3-22.

https://doi.org/10.5054/tj.2010.214879

Dyson, A. H. (1997). Writing superheroes: Contemporary childhood, popular culture, and classroom literacy. New York: Teachers College Press.

Dyson, A. H. (2013). ReWRITING the basics: Literacy learning in children's cultures. New York: Teachers College.

Emerson, R., Fretz, R., \& Shaw, L. (1995). Writing ethnographic fieldnotes. Chicago, IL: University of Chicago Press.

Erickson, F. (1986). Qualitative methods in research on teaching. In M. Wittrock (Ed.), Handbook of research on teaching (3rd ed., pp. 119-161). Washington, DC: American Educational Research Association (AERA).

Fan, Y. (2013). Every teacher is a language teacher: Preparing teacher candidates for English language learners with service learning. International Journal of Community Research and Engagement, 6, 77-92. http://dx.doi.org/10.5130/ijcre.v6i1.3232

Fillmore, L. W., \& Snow, C. (2002). What teachers need to know about language. In C. Adger, C. Snow, \& D. Christian (Eds.), What teachers need to know about language (pp. 7-54).

HcHenry, IL: Delta Systems.

Fillmore, L. W. (2014). English language learners at the crossroads of educational reform. TESOL Quarterly, 48, 624-632. https://doi.org/10.1002/tesq.174

Gebhard, M. (1998). A case for professional development schools. TESOL Quarterly, 32, 501510. http://www.jstor.org/stable/3588120 
García, E., Arias, M. B., Murri, N. J. H., \& Serna, C. (2010). Developing responsive teachers: A challenge for a demographic reality. Journal of Teacher Education, 61, 132-142.

https://doi.org/10.1177/0022487109347878

Hadjioannou, X., \& Hutchinson, M. C. (2010). Putting the G back in English: Preparing preservice teachers to teach grammar. English Teaching: Practice and Critique, 9, 90-105. https://files.eric.ed.gov/fulltext/EJ912625.pdf

Halliday, M. \& Halliday, M. (Ed.) (2004 [1980]). Three aspects of children’s language development: learning language, learning through language, learning about language in Halliday, M.A.K. (Ed.) The Language of Early Childhood: Vol. 4 The Collected Works of M.A.K. Halliday (Vol. 4). London: Continuum.

Houston, W. R., Hollis, L. Y., Clay, D., Ligons, C. M., \& Roff, L. (1999). Effects of collaboration on urban education programs and professional development schools. In D. M. Byrd \& D. J. McIntyre (Eds.), Research on professional development schools. Teacher education yearbook VII (pp. 6-28). Thousand Oaks, CA: Corwin Press.

Hymes, D. (1972). On communicative competence. In J. Pride \& J. Holmes (Eds.), Sociolinguistics: Selected readings (pp. 269-293). Harmondsworth, UK: Penguin.

Hymes, D. (1974). Foundations in sociolinguistics: An ethnographic approach. Philadelphia: University of Pennsylvania Press.

Jackson, P. W. (1990). Life in classrooms. New York: Teachers College Press.

Jurchan, J., \& Morano, T. A. (2010). The case study: Bringing real-world experience into the teacher preparation program. TESOL Journal, 1, 71-84. https://doi.org/10.5054/tj.2010.214880

Lave, J., \& Wenger, E. (1991). Situated learning: Legitimate peripheral participation. Cambridge: Cambridge University Press.

Lopez, F., \& Iribarren, J. (2014). Creating and sustaining inclusive instructional settings for English language learners: Why, what, and how. Theory Into Practice, 53, 106-114.

https://doi.org/10.1080/00405841.2014.885810

Lucas, T., Villegas, A. M., \& Freedson-Gonzalez, M. (2008). Linguistically responsive teacher education: preparing classroom teachers to teach English language learners. Journal of Teacher Education, 59, 361-373. https://doi.org/10.1177/0022487108322110

Lucas, T., \& Villegas, A. M. (2013). Preparing Linguistically Responsive Teachers: Laying the Foundation in Preservice Teacher Education. Theory Into Practice, 52, 98-109. https://doi.org/10.1080/00405841.2013.770327

Major, E. M. (2006). Secondary teachers as cultural mediators for language minority students. The Clearing House: A Journal of Educational Strategies, Issues and Ideas, 80, 29-32. https://doi.org/10.3200/TCHS.80.1.29-32 
Moll, L., Amanti, C., Neff, D., \& Gonzalez, N. (1992). Funds of knowledge for teaching: Using a qualitative approach to connect homes and classrooms. Theory Into Practice, XXXI, 132141. https://doi.org/10.1080/00405849209543534

Osborne-Wilson, C., Sinatra, R., \& Baratta, A. (1989). Helping Chinese students in the literacy transfer process. Journal of Reading, 32, 330-336. http://www.jstor.org/stable/40029931

Ponder, J., Veldt, M. V., \& Lewis-Ferrell, G. (2011). Citizenship, curriculum, and critical thinking beyond the four walls of the classroom: Linking the academic content with service-learning. Teacher Education Quarterly, 38, 45-68. http://www.jstor.org/stable/23479630

Richard, J. C., \& Rodgers, T. S. (2014). Approaches and methods in language teaching. Cambridge: Cambridge University Press.

Rogoff, B. (2003). The cultural nature of human development. New York: Oxford University Press.

Rothenberg, C. \& Fisher, D. (2007). Teaching English language learners: Differentiated approach. Columbus, $\mathrm{OH}$ : Pearson.

Rubinstein-Avila, E., \& Lee, E. H. (2014). Secondary Teachers and English Language Learners (ELLs): Attitudes, Preparation and Implications. The Clearing House: A Journal of Educational Strategies, Issues and Ideas, 87, 187-191. https://doi.org/10.1080/00098655.2014.910162

Swain, M. (2013). The inseparability of cognition and emotion in second language learning. Language Teaching, 46, 195-207. https://doi.org/10.1017/S0261444811000486

Trachtman, R. (2007). Inquiry and accountability in professional development schools. Journal of Educational Research, 100, 197-203. https://doi.org/10.3200/JOER.100.4.197-203

Turkan, S., de Oliveira, L. C., Lee, O., \& Phelps, G. (2014). Proposing a knowledge base for teaching academic content to English language learners: Disciplinary linguistic knowledge.

Teachers College Record, 116, p. -. http://www.tcrecord.org ID Number: 17361, Date Accessed: 5/26/2018 6:39:32 PM

U. S. Department of Education. (2012). The condition of education 2011 (National Center for Education Statistics 2011-045), indicator 6.

U. S. Department of Education. (2013). Digest of education statistics: Advance release of selected 2012 digest tables, table 47.

Valdés, G. (2001). Learning and not learning English: Latino students in American schools. New York: Teachers College Press.

Vélez-Rendón, G. (2002). Second language teacher education: A Review of the literature. Foreign Language Annals, 35, 457-467. https://doi.org/10.1111/j.1944-9720.2002.tb01884.X 
Vygotsky, L. S. (1978). Mind in society. Cambridge, MA: Harvard University Press.

Waxman, H. C., \& Tellez, K. (2002). Research synthesis on effective teaching practices for English language learners. Philadelphia, PA: Temple University.

Wenger, E. (2009). Social learning capacity: Four essays on innovation and learning in social systems. Retrieved July 8, 2016, from http://wenger-trayner.com/wp-content/uploads/2011/12/0904-17-Social-learning-capability-v2.1.pdf.

Wong, P. L., \& Glass, R. D. (2009). Introduction: The Equity Network: The contextual and theoretical frameworks for urban professional development schools. In P. L. Wong \& R. D. Glass (Eds.), Prioritizing urban children, teachers, and schools through professional development schools (pp. 1-26). Albany, NY: SUNY.

Wong, P. L., \& Glass, R. D. (2011). Professional development schools and student learning and achievement. National Society for the Study of Education Yearbook, 110, 403-431.

Zuengler, J. \& Miller, E. R. (2006). Cognitive and sociocultural perspectives: Two parallel SLA worlds? TESOL Quarterly, 40, 35-58. https://doi.org/10.2307/40264510 